\title{
THE MEDIATION ROLE OF BRAND LOVE AND EXPERIENCE IN THE EFFECT OF SELF BRAND CONNECTION ON THE BRAND LOYALTY
}

DOI: 10.17261/Pressacademia.2019.1106

PAP- V.9-2019(53)-p.285-294

\section{Aysel Ercis ${ }^{1}$, Oguz Han Aykut ${ }^{2}$, Tugba Yildiz ${ }^{3}$}

${ }^{1}$ Atatürk University, Faculty of Economics and Administrative Sciences, Erzurum, Turkey. ayselercis@atauni.edu.tr, ORCID: 0000-0002-9835-8574

2Erzincan Binali Yıldırım University, Erzincan Vocational School, Marketing, Erzincan, Turkey. oaykut@erzincan.edu.tr, ORCID:0000-0002-3243-9881

${ }^{3}$ Bayburt University, Demirözü Vocational School, The Cooperative Programme, Bayburt, Turkey. tugbayildiz@bayburt.edu.tr , ORCID: 0000-0003-0260-0555

To cite this document

Ercis, A., Aykut, O.H., Yildiz, T., (2019). The mediation role of brand love and experience in the effect of self brand connection on the brand loyalty. PressAcademia Procedia (PAP), V.9, p.285-294

Permemant link to this document: http://doi.org/10.17261/Pressacademia.2019.1106

Copyright: Published by PressAcademia and limited licenced re-use rights only.

\section{ABSTRACT}

Purpose- Nowadays, many reasons such as the rapid development of technology and the differences in the demands and needs of the consumers have led the enterprises to identify the elements that can distinguish themselves from their competitors. Therefore, researching the elements that can create brand loyalty is very important in terms of developing the right strategies.The aim of the study is to investigate the mediation role of brand love and brand experience in the effect of self-brand connection on brand loyalty.

Methodology-The research population consists of university students aged 18 years and older living in Erzincan province. After the validation and cleaning of data by removal missing entries, a total of 300 respondet data points is available for carrying out further analysis.

Findings- The results show that the self-brand connection has a significant effect on brand loyalty. In addition to this, it is determined that brand love and brand experience have mediation roles in the effect of self-brand connection on brand loyalty.

Conclusion- In order to create brand loyalty, brand love, brand experience and self brand connection are important.

Keywords: Self-brand connection, brand love, brand experience, brand loyalty

JEL Codes: M30, M31.

\section{BENLIK-MARKA BAĞININ MARKA SADAKATI ÜZERINDEKI ETKISINDE MARKA AŞKI VE DENEYIMININ ARACILIK ROLÜ}

\section{ÖZET}

Amaç- Günümüzde teknolojinin hızla gelişmesi, tüketicinin istek ve ihtiyaçlarının farklılık göstermesi gibi birçok sebep işletmeleri kendilerini rakiplerinden ayırt edebilecek unsurlar tespit etmeye itmiştir. Bu yüzden marka sadakati oluşturabilecek öğelerin araştırılması doğru stratejilerin geliştirilmesi açısından oldukça önemlidir. Bu araştırmanın amacı, benlik-marka bağının marka sadakati üzerindeki etkisinde, marka aşkı ve marka deneyiminin aracılık rolünün araştırılmasıdır.

Yöntem- Araştırmanın ana kütlesini Erzincan il sınırlarında yaşayan 18 yaş ve üzeri üniversite öğrencileri oluşturmaktadır. Anketlerin hatalı ve eksik cevapları elendikten sonra 300 adet anket formu değerlendirmeye tabi tutulmuştur.

Bulgular- Elde edilen sonuçlar benlik-marka bağının marka sadakati üzerinde anlamlı etkiye sahip olduğunu göstermektedir. Bununla birlikte benlik-marka bağının marka sadakati üzerindeki etkisinde marka aşkı ve marka deneyiminin aracılık rolleri olduğu tespit edilmiştir.

Sonuç- Marka bağıı̆ı̆ı yaratmada benlik marka bağı, marka deneyimi ve marka aşkı etkilidir.

Anahtar Kelimeler: Benlik marka bağı, marka aşkı, marka deneyimi, marka sadakati JEL Kodları: M30, M31. 


\section{GíRiş}

Pazardaki ürünlerin kolay biçimde taklit edilebilmesi, firmaların benzer nitelikteki ürünleri kolaylıkla pazarlara sunabilmeleri ve sürekli artan rekabet değerli marka yaratmanın önemini daha da artırmıştır. Bu nedenle işletmeler, kendilerine özgü değerleri, özellikleri, karakteristikleri yansıtan farklı markalar yaratmak zorunda kalmışlardır (Kotler ve Keller, 2009: 277). Literatürde yer alan çalışmalarda; Brakus ve diğ. (2009), Chang ve Chieng (2006), Nadiri ve Günay (2013) ile Zarantonello ve Schmitt (2010), doğru pazarlama çabaları neticesinde memnuniyet duygusu geliştiren müşterilerin marka deneyimlerinin zaman içerisinde müşteri sadakatine dönüştüğü sonucuna ulaşmışlardır. Müşteriler kendileriyle özdeşleştirdikleri markaların cazibesine kapılmaktadırlar. Bu nedenle müşteri ve marka arasındaki bağlantı müşterinin markayı kendisiyle benzeştirmesiyle harekete geçmekte, markanın imajı ve kişilik özellikleri aracılığıyla gelişmektedir (Ridgway, 2011: 20).

İşletmeler, markaların somut özelliklerine odaklanmaktan ziyade müşterilerinin duygularına ve kalplerine hitap ettikçe, müşterilerine fayda sağladıkça ve bireylerin hayatlarına değer kattıkça rekabet ortamında avantaj sahibi olabileceklerdir (Knapp, 1999: 8-9). Huang (2017) marka deneyimi üzerinde marka aşkının etkisini incelemiş; marka aşkının hem davranışsal hem de tutumsal marka sadakati üzerinde etkili olduğunu bulmuştur. Benzer şekilde Alnawas ve Altarifi (2016) yaptıkları çalışmalarında marka aşkı ve sadakati arasında olumlu bir ilişki olduğunu belirlemişlerdir. Yang ve diğ. (2017) ise marka deneyimin marka sadakati üzerinde etkisi olduğunu ifade etmişlerdir. Yine Hussein (2018) olumlu marka deneyiminin marka sadakati üzerinde pozitif etkisi olduğu sonucuna ulaşmıştır. Van der Westhuizen (2018) yaptığı çalışmada benlik-marka bağının marka deneyimi ile olumlu bir ilişkisi olduğu sonucuna ulaşmış, benlik-marka bağı ve marka sadakati arasında marka deneyiminin aracılık etkisi olduğunu da belirtmiştir. Eelen ve diğ. (2017) benlik-marka bağı üzerinde yaptıkları çalışmalarında ise marka sadakati ile benlik-marka bağı arasında pozitif ilişki olduğu sonucuna varmışlardır. Grubb ve Grathwohl (1967) bireyin benliğiyle uyumlu olan markları veya ürünleri tercih etmesini benlik teorisiyle açıklamışlardır. Benlik uyumu benlik kavramının doğal bir uzantısı olarak düşünülmektedir. Benlik uyum teorisindeki temel varsayım, bir tüketicinin, kendi benliğine uyan ürün veya markaları seçme eğiliminde olduğu yönündedir. Bu varsayım uyum derecesi ne kadar yüksekse satın alma niyetinin de o kadar yüksek olduğunu ortaya koymaktadır (Sirgy ve diğ., 1991: 364; Uşaklı ve Baloğlu, 2011: 116). Liu ve diğ. (2012) markaya yönelik tutum ve sadakat üzerinde benlik uyumunun etkisi olduğunu belirtmişlerdir. İlgili literatür desteği doğrultusunda marka sadakatine etki eden değişkenler olarak benlik-marka bağı, marka aşkı ve marka deneyimi olarak ele alınmış, ayrıca marka deneyimi ve marka aşkının aracılık etkisi araştırılarak yazına katkı sağlanması amaçlanmıştır. Çalışma dört bölümden oluşmaktadır. İlk bölümde; benlik-marka bağı, marka sadakati, marka aşkı ve marka deneyimi kavramları hakkında literatür taraması yapılarak açıklamalar sunulmuştur. İkinci bölümde; çalışmanın amacı, yöntemi, sınırları, kullanılan ölçekler, model ve hipotezler hakkında bilgiler verilmiştir. Üçüncü bölümde; bulgular değerlendirilerek analizler yapılmış olup, son bölümde ise sonuçlar belirtilerek bir takım önerilerde bulunulmuştur.

\section{TEORIK ÇERÇEVE}

\subsection{Benlik-Marka Bağı}

Benlik-marka bağı benlik uyum işleyiş biçimiyle alakalıdır. Tüketicinin kimliğini oluşturan ve bu kimlikle uyum sağlayan unsurları ele almaktadır (Aguirre-Rodriguez ve diğ., 2012: 1180). Diğer bir ifadeyle benlik-marka bağı; “Bireyin benliğine markayı ne ölçüde dâhil ettiği veya benliğiyle birleştirme derecesidir." (Escalas, 2004: 170; Escalas ve Bettman, 2005: 378). Van der Westhuizen (2018: 173) ise benlik-marka bağını özel bir marka ile tüketici arasındaki benlik bağı olarak ifade etmiştir. Benlik-marka bağı tüketicilerin benliklerinin oluşmasında önemli bir rol oynamaktadır. Benlik-marka bağı kavramında bireyler; kendilerini kimlik hedeflerine ulaştıracak, kimliklerinin oluşmasına yardımcı olacak, kendilerini temsil edebilecek, kimlik görünümlerini hem kendilerine hem de diğer bireylere sunabilecek ürün ve markaları kullanmak istemektedirler. Yine marka ve tüketici arasında oluşan kuvvetli ve anlamlı bağ benlik-marka bağı ile ifade edilmektedir (Escalas ve Bettman: 2003, 340). Benlik-marka bağı oldukça öznel bir yapıdır. Bir başka ifadeyle benlik-marka bağı, tüketici odaklı olup kişisel ilişkiler üzerine odaklanmaktadır (Van der Westhuizen, 2018: 172). Erciş ve diğ. (2017) yaptıkları çalışmada ideal ve gerçek benlik uyumunun duygusal marka bağ|ılığı üzerinde etkisi olduğunu belirtmişlerdir. Benlik-marka bağı yüksek olan müşteriler markaya yönelik olumlu bakış açısına sahiptirler. Çünkü benlik bağı hem bireyin markaya güçlü duygular beslemesine hem de markaya yönelik davranışsal boyuta önemli etkiler yaratmaktadır (Ferraro ve diğ., 2013: 477). Hemsley-Brown ve Alnavas (2016) yaptıkları çalışmalarında benlik-marka bağı ile marka sadakati arasında olumlu bir ilişki olduğunu ifade etmiştirler. Hwang ve Kandampully (2012) yaptıkları çalışmalarında müşterinin benlik-marka bağı arttıkça markaya duyduğu aşkın, duygusal marka sadakatinin ve marka yönelik tutumsal sadakatinin artacağı sonucuna ulaşmışlardır. Lee ve Jeong (2014) ise benlik imaj uyumunun online marka deneyimi üzerinde olumlu etkisi olduğunu belirtmişlerdir.

\subsection{Marka Aşkı}

Tüketici davranışlarına olumlu yönde etki eden, ürünlerin fiyatları ne olursa olsun tüketicilerin tekrar tekrar satın almalarını sağlayan, hakkında tüketicilerde pozitif izlenimler oluşturan kavrama marka aşkı denir. Diğer bir ifadeyle tüketicilerin markalara duygusal yönden kendilerini yakın hissedip bağlanmalarını sağlayan durum markalara duyulan aşkla izah edilmektedir. Son yıllarda özellikle tüketici davranışları alanında yoğun bir şekilde ele alınan marka aşkı; bir markayı veya ürünü kullanmak suretiyle tatmin olan bir tüketicinin sahip olduğu tutkulu duygusal bağııı̆ın derecesi şeklinde tanımlanmaktadır (Carroll ve Ahuvia, 2006: 81). Marka aşkı bireyler arası aşk ve bağı teorilerini temel almaktadır. Bu bağlamda tüketici ile marka arasındaki ilişkinin bireyler arasındaki aşk ve bağlılıkla benzerlik göstermesi birtakım araştırmacıları bireyler arası aşk teorilerini tüketici araştırmalarına adapte etmeye yönlendirmiştir (Garg ve diğ., 2016: 136).

Samimiyet, tutku ve karar/bağııık boyutlarından oluşan Stenberg'in (1986) Üçgen Aşk Teorisi bireyler arası aşk ile ilgili yapılmış en önemli kuramlardan birisidir. Üçgen Aşk Teorisini esas alarak tüketici ile tüketim nesnesi arasındaki ilişkinin incelendiği çalışmalarında Shimp ve Madden (1988), tüketicilerin tüketim nesnelerine yönelik hislerini ve aşk duygularını inceleyerek aşk kavramını pazarlama disiplinine dâhil etmişlerdir. Söz konusu çalışmada tüketici ile tüketim nesnesi arasındaki bağlantı beğenme, özlem ve karar/bağlılık boyutları olmak üzere üçe ayrılmıştır. İlişkinin beğenme boyutu; bağıılık ve düşkünlük gibi duyguları ifade ederken (örneğin; bir çocuğun sevdiği oyuncak bebekten ayrılmaması), özlem boyutu; tüketicinin nesneye sahip olmaya yönelik güçlü ve kuvvetli arzusunu (örneğin; bireyin özel bir spor arabaya sahip 
olma arzusu) ifade etmektedir. İlişkinin karar boyutunda; tüketicinin kısa dönemde markanın ya da tüketim nesnesinin özelliklerinin/yararlarının tüketicinin beklentilerine dönük olmasından dolayı belli bir malı, hizmeti ya da markaya karşı sevgi duyması söz konusuyken bağlılık boyutunda ise tüketicilerin tüketim nesnelerine duydukları sevginin sürekliliği söz konusudur (Shimp ve Madden, 1988: 164-165).

Ahuvia (1993) çalışmasında bireylerin aşk duydukları nesnelere karşı yoğun duygular hissettiğini ve aşk duyulan nesnenin ise kişiden kişiye göre değişkenlik gösterdiğini ifade etmektedir. Fournier (1998) çalışmasında ise tüketicilerin markalarla kurdukları uzun süreli ilişkilerde markalara duyulan aşkın önemini incelemiştir. Marka ve aşk içerikli çalışmalar ele alındığında, tatminkâr bireylerin belirli bir markaya karşı duydukları hisleri belirtmek üzere literatürde marka aşkı adıyla yeni bir olgu ortaya çıkmıştır. Marka aşkı kavramının temelinde, bireylerin markalar hakkında hissettiklerini nicel olarak ölçmek ve tatminkâr bireylerin markaya karşı hislerindeki farklılıkları net bir şekilde ortaya çıkarma düşüncesi yer almaktadır (Carroll ve Ahuvia, 2006: 80-81).

\subsection{Marka Deneyimi}

Marka deneyimi kavramının pazarlama çabalarında gittikçe önemli bir yer edinmesi ile birlikte pazarlamacılar, marka deneyiminin gelişen pazarlama stratejilerinin etkinliği açısından oldukça kritik bir öneme sahip olduğunu fark etmeye başlamışlardır (Brakus ve diğ., 2009: 52). Marka deneyimi; müşterinin pazarda karşılaştığı ürünün kendisi, logosu, ismi, ambalajı, broşürü ve reklamı ile yaşadığı tecrübeleri kapsayan stratejik unsurlardır (Schmitt, 2003: 117). Marka deneyiminin temelinde deneyimsel pazarlama ve onun uygulamaları yer almaktadır. Marka deneyimi, marka ile ilgili bütünsel bir değerlendirme olup (Khan ve Rahman, 2015: 61) markaya yönelik duyusal uyarıcılarla karşılaşma anında bu uyarıcılara verilen yanıt olarak ortaya çıkmaktadır (Chang ve Chieng, 2006: 931).

Müşteriler marka deneyimini ürüne temas ettiklerinde, ürünle karşılaştıkları an hissettiklerinde, herhangi bir kitle iletişim aracında gördüklerinde veya mağaza tasarımında yaşamaktadırlar. Kısacası bir markanın herhangi bir etkinliğine katılmak, reklamlarıyla karşılaşmak, logosunu veya ismini duymak, o markayı daha önceden kullanmış kişilerden olumlu veya olumsuz fikirler almak gibi tüm olaylar o marka ile deneyim yaşanması ile sonuçlanmaktadır (Brakus ve diğ., 2009: 53). Marka deneyimi bireysel ve ortak deneyimler olmak üzere iki kategoriye ayrılmaktadır. Duyusal, duygusal ve düşünsel deneyimler bireysel deneyimler olarak kabul edilirken; davranışsal ve ilişkisel deneyimler ise ortak deneyimler olarak kabul edilmektedir (Chang ve Chieng, 2006: 931).

Duyusal Marka Deneyimi; Duyusal marka deneyimi; beş duyu organı yardımıyla bireylerin zihninde oluşmaktadır (Dirsehan 2010: 33). Marka, bireylerde ne kadar fazla duyu organına hitap eder ve güçlü bir duyusal uyum sağlarsa, bireylerde o kadar fazla ilgi yaratmaktadır. Bu durumun temelinde her duyunun bir diğeriyle içsel bir bağının olması yer almaktadır. Bir başka ifadeyle marka ile beş duyu arasında anlamlı ve güçlü bir sinerji yaratılabilirse, markanın da bireylere yaşatacağı deneyim o kadar çekici ve etkili olmaktadır (Schmitt ve Rogers, 2008: 209).

Duygusal Marka Deneyimi; Duygusal marka deneyimi; markaya yönelik hafif duygulardan güçlü duygulara kadar farklılık barındıran, bireylerin özel hislerine ve duygularına yönelik deneyimlerdir (Konuk, 2014: 40). Bireyler satın alma davranışı sergilerken ürün ya da marka ile ilgili duygularına bağı olarak tercihlerde bulunmaktadırlar. Bu nedenle duyguların ve duygularla birlikte yaşanılan deneyimlerin markalama için önemli olduğu bilinmektedir (Batı, 2013: 115). Duygusal deneyimler bireylerin anılarında ve fantezilerinde yer alarak marka hakkında olumlu duygular oluşturabilmelerine yardımcı olmaktadır (Beckman ve diğ., 2014: 648). Bu nedenle işletmeler pozitif duygular ortaya koyan iyi bir pazarlama stratejisi sayesinde müşterileriyle uzun süreli ve güçlü bir marka sadakati sağlayabilmektedirler (Konuk, 2014: 40).

Düşünsel Marka Deneyimi; Düşünsel marka deneyimi; bireylerde ilgi ve merak uyandırarak bilişsel problem çözme deneyimleridir. Akla hitap eden bu deneyim marka, ürün ve işletmelerin tekrar değerlendirilebilmesi için bireyleri etraflıca düşünmeye yönlendirmektedir. Bu nedenle başarılı bir düşünsel deneyimin unsurlarını; görsel, sözel veya zihinsel olarak bireylerin talep ettiklerinden fazlasını, umut ettiklerinden daha iyisini sunarak şaşkınlık yaratıp ilgilerinin çekilmesi oluşturmaktadır (Schmitt, 1999: 61).

Davranışsal Marka Deneyimi; Davranışsal marka deneyimi; bireylerin yaşam biçimlerini, fiziksel olarak yaşadıkları deneyimleri ve diğer bireylerle olan iletişim biçimlerini etkilemektedir (Schmitt, 1999: 62). Davranışsal marka deneyimleri sayesinde işletmeler bireylere yaşamlarını zenginleştirecek eşsiz deneyimler sunmaktadırlar (Beckman ve diğ., 2014: 648).

Ilişskisel Marka Deneyimi; iliş̧kisel marka deneyimi; yukarıda bahsedilen marka deneyimlerinin sonucu oluşan ve deneyim vasıtasıyla birey ve marka arasında bağlantı kurmaya odaklı bir stratejidir. Bireyin; içinde bulunduğu sosyal sınıf, ait olduğu sosyal kimlik, marka ile kurdukları iletişim, ortaya çıkardığı sosyal etki, ideal rol modelleri, mensubu olduğu gruplar ve sahip olduğu kültürel unsurları ilişkisel marka deneyiminin oluşmasında önem arz etmektedir (Schmitt, 2010: 69).

\subsection{Marka Sadakati}

Marka sadakati; tüketiciler tarafından tercih edilen bir markanın ürünlerini satın alan, markadan vazgeçmeye sebebiyet verecek koşullar ve rakiplerin sergilemiş oldukları pazarlama çabalarına rağmen aynı markanın ürünlerinin yine tüketiciler tarafından gelecekte de sürekli olarak satın alınacağının veya tekrar tüketicisi olunacağının sözüdür (Oliver, 1999: 34). Diğer bir ifadeyle marka sadakati; tüketicinin bir markaya duyduğu bağııı̆ının bir göstergesi olup markanın fiyatında veya ürünün niteliklerinde olası bir değişiklik yapılması durumunda tüketicinin başka markaları tercih etmesinin ne kadar olası olduğunu yansıtan bir kavramdır (Aaker, 2009: 58). Fitzgibbon ve White (2004: 215) ise marka sadakatini; bir mal veya hizmete karşı sergilenen olumlu bir tutum ve o mal veya hizmetin tutarlı bir şekilde satın alınması olarak tanımlamışlardır.

Marka sadakati işletmelere rekabet avantajı sağladığı için oldukça önemlidir. Değişen dünya ile birlikte günümüzde işletmeler özellikle fiyat bazlı rekabetin yaşandığı pazarlarda kendi markalarını satın alan sadık tüketici profilleri oluşturmayı amaçlamaktadır. Marka sadakati, markanın gün geçtikçe artan öneminin en temel nedenleri arasında yer almaktadır. Bu sebeple işletmeler, tüketicilerde kendi markalarına yönelik sadakat yaratmak için çok ciddi yatırımlar yapmaktadırlar (Onan, 2006: 98). Marka sadakatinin ölçülmesi işletmelere büyük katkılar 
sağladığı için oldukça önem ifade etmektedir (Ha, 1998: 51). Marka sadakatini doğru ölçebilen işletmeler hem bakış açılarını genişletmekte hem de sadakati karlııkla ilişkilendirebilmektedir. Bu nedenle işletmeler müşterileriyle daha fazla bağlantı kurmaya çalışmalı ve müşterilerinin intiyaçlarını karşılayabilmelidirler (Schoenbachler ve diğ., 2004: 488). Algharabat (2017) yaptığı çalışmada marka sadakati üzerinde marka aşkının etkisi olduğu sonucuna ulaşmıştır. Marka sadakati kavramı ile ilgili yapılan çalışmalar incelendiğinde, sadakat ölçümlerinde davranışsal ve tutumsal olmak üzere iki tür yaklaşımın olduğu görülmüştür.

Davranısssal Sadakat Yaklașımı; Davranışsal sadakat; müșterilerin satın alma davranışları, alışkanlıkları ve müşterilerin ișletmenin aynı markalı ürünlerinin geçmişe dönük satın alma davranışlarının hesaplanmasıyla ifade edilir (Mascarenhas ve diğ., 2006: 399). Davranışsal sadakat yaklaşımının en önemli avantajı, niyet ve beklentilerin yerine gerçek verilere dayanmasıdır. Bu sayede verilerden oluşan gözlemlenebilir davranışların ölçümü tutumsal sadakat yaklaşıma göre son derece kolay ve ucuz olacaktır (Brink ve diğ., 2006: 17).

Tutumsal Sadakat Yaklaşımı; Tutum; bireylerin aile, arkadaş çevresi ve sosyal çevrelerinde araştırma yapıp bilgi edindikten veya deneyim elde ettikten sonra zaman içerisinde ortaya çıkardıkları veya geliştirdikleri bir davranıştır (Fandos ve Flavian, 2006: 650). Tutumsal sadakat ise tüketicinin markaya yönelik olumlu duygular besleyip marka ile ilişkisini sürdürmesiyle veya bir tercih söz konusu olduğunda aynı markayı seçmesiyle açıklanmaktadır (Mascarenhas ve diğ., 2006: 399). Tutumsal marka sadakati belirli bir markanın kendisine özgü değerleri olduğunu ve bu değerlerin ise sadakati kuvvetlendirdiğini ifade etmektedir (Chaudhuri ve Holbrook, 2001: 82).

\section{METODOLOJi}

\subsection{Araştırmanın Amacı, Kapsamı ve Kısıtları}

$\mathrm{Bu}$ araştırmanın amacı; tüketicinin kimliğini oluşturan ve bu kimlikle uyum sağlayan unsurların mal veya hizmetin tutarlı bir şekilde satın alınması üzerindeki etkisinde markalara duygusal yönden kendilerini yakın hissetmelerinin ve yaşadıkları tecrübelerin aracılık rolünü araştırmaktır. Araştırma yüz yüze anket uygulaması yöntemiyle Erzincan merkez ilçede 18 yaş ve üstü cep telefonu kullandığını ve genellikle belirli bir markayı tercih ettiğini ifade eden 384 üniversite öğrencisinin katılımıyla gerçekleştirilmiştir. 384 kişiye uygulanan anketin hatalı ve eksik cevapları elendikten sonra 300 adet anket formu değerlendirmeye tabi tutulmuştur. Elde edilen sonuçlar bu örneklem için geçerli olup, diğer ürün grupları, markalar ve şehirler için genellenemez.

\subsection{Araştırmanın Modeli ve Hipotezler}

İlgili teoriden hareketle araştırmanın kapsamına; benlik-marka bağı, marka sadakati, marka aşkı ve marka deneyimi değişkenleri dâhil edilmiştir. Bu değişkenler arasındaki ilişkiler ise kuramsal bilgiler ışığında kurgulanmış olup bu doğrultuda araştırma modeli ve hipotezleri geliştirilmiştir.

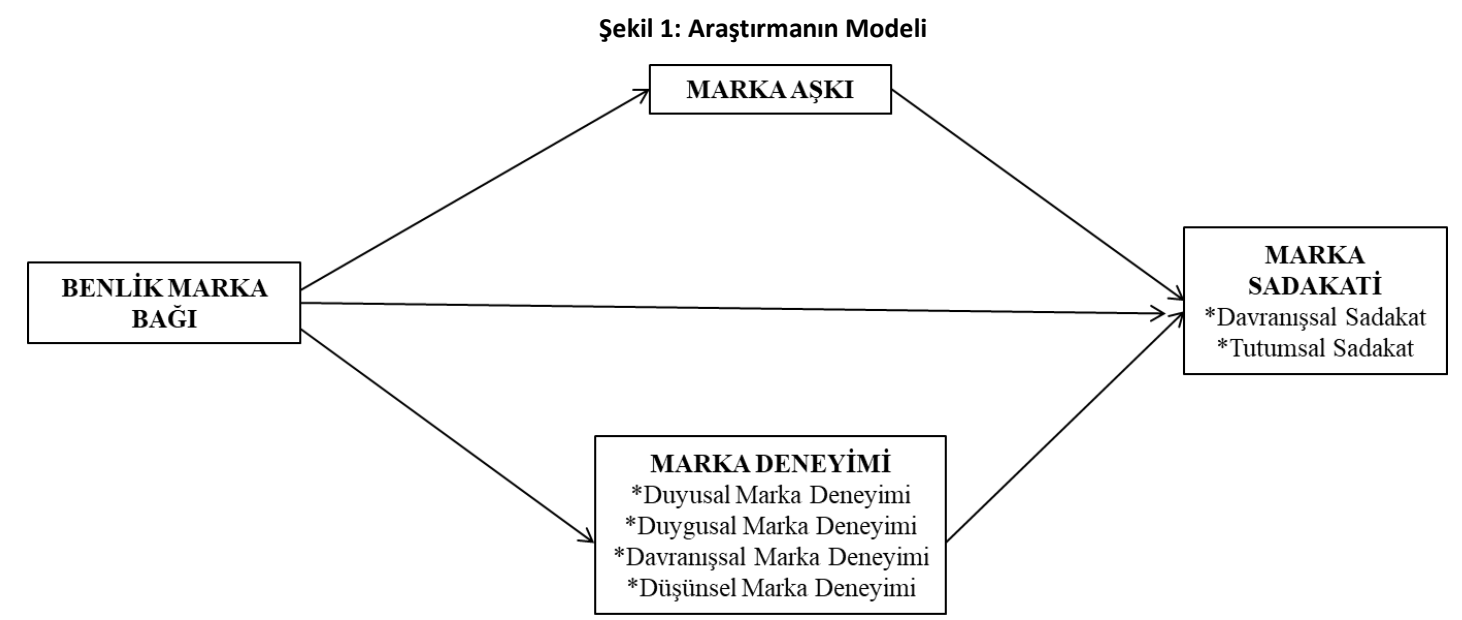

Araştırmanın amacı ve modeli doğrultusunda test edilmek üzere aşağıdaki hipotezler geliştirilmiştir:

$\mathrm{H}_{1}$ : Benlik-marka bağının marka aşkı üzerinde etkisi vardır.

$\mathrm{H}_{2}$ : Benlik-marka bağının marka deneyimi üzerinde etkisi vardır.

$\mathrm{H}_{3}$ : Benlik-marka bağının marka sadakati üzerinde etkisi vardır.

$\mathrm{H}_{4}$ :Marka aşkının, benlik-marka bağı ile marka sadakati arasında aracılık etkisi vardır.

$\mathrm{H}_{5}$ :Marka deneyiminin, benlik-marka bağı ile marka sadakati arasında aracılık etkisi vardır.

$\mathrm{H}_{6}$ : Marka aşkının marka sadakati üzerinde etkisi vardır.

$\mathrm{H}_{7}$ : Marka deneyiminin marka sadakati üzerinde etkisi vardır.

\subsection{Veri Toplama Yöntem ve Süreci}

Araştırmanın ana kütlesini Erzincan'da yaşayan 18 yaş ve üzeri üniversite öğrencileri oluşturmaktadır. Araştırma verileri yüz yüze anket yöntemi kullanılarak elde edilmiştir. Örneklem yöntemi olarak, kolayda örnekleme yöntemi kullanılmıştır. 
Anket formunda yer alan sorular dört farklı gruptan oluşmaktadır. Birinci grupta yer alan sorular kullanıcıların tercih ettikleri cep telefonu markasına yönelik benlik-marka bağını belirlemek amacıyla sorulmuş olup Escalas ve Bettman (2003) tarafından geliştirilen ölçekten alınmışır. İkinci grupta yer alan sorular kullanıııların tercih ettikleri cep telefonu markasına yönelik marka aşklarıı belirlemek amacıyla sorulmuş olup Carroll ve Ahuvia (2006) tarafından geliştirilen ölçekten alınmış̦ır. Üçüncü grupta yer alan sorular kullanıcıların tercih ettikleri cep telefonu markasına yönelik marka deneyimlerini belirlemek amacıyla sorulmuş olup Brakus ve diğ. (2009) tarafından geliştirilen ölçekten alınmıştır. Dördüncü grupta yer alan sorular ise kullanıcıların tercih ettikleri cep telefonu markasına yönelik marka sadakatlerini belirlemek amacıyla sorulmuş olup Chaudhuri ve Holbrook (2001) ile Kumari ve Patyal (2017) tarafından geliştirilen ölçekten alınmıştır. Anketin son bölümünde ise demografik özellikler ile ilgili sorular yer almaktadır.

Ölçekler çevrilirken dil uzmanlarına başvurulmuş olup, anket sorularının çevrilmesinde ortaya çıkabilecek olan yanlışlıkları ortadan kaldırabilmek amacıyla ölçeklerin çevirisi yaptııılmıştır. Ölçeklerin çevirisi yapıldıktan sonra 20 kişilik bir örnekleme ön çalışma uygulanmış ve ankete son şekli verilmiştir. Anket çalışması 03.12.2018 -21.12.2018 tarihleri arasında yapılmışıı. Kesin anket formu düzenlendikten sonra 384 kişiye anket uygulanmış yanlış ve eksik doldurulan anketler elendikten sonra 300 anket formu değerlendirmeye alınmıştır. Veriler SPSS 22.0 paket programında analiz edilmiştir. Verilere; tanımlayıcı istatistikler, güvenilirlik analizi ile doğrusal ve hiyerarşik regresyon analizleri uygulanmıştır.

\section{ARAŞTIRMA BULGULARI}

\subsection{Demografik Özellikler}

Araştırmaya katılanların demografik özelliklerine ilişkin bilgiler şu şekildedir: Katılımcıların \%55,7'si erkek ve \%44,3'ü kadındır. Katılımcıların yaş gruplarına göre dağılımlarında; çoğunluğu \%83,3 ile 18-24 yaş grubu oluşturmaktadır. Katılımcıların genel olarak \%61,3 ile 1000 TL ve altı gelire sahip oldukları görülmektedir.

\section{2. Ölçeklere İlişkin Güvenilirlik Analizi}

Tablo 1: Güvenilirlik Sonuçları

\begin{tabular}{ll}
\hline Değişkenler & Cronbach's Alpha Değeri \\
\hline Benlik-marka Bağı & 0,91 \\
Marka Aşkı & 0,92 \\
Marka Deneyimi & 0,91 \\
Marka Sadakati & 0,96 \\
\hline
\end{tabular}

Tablo 1'e bakıldığında ölçeklerin güvenilir olduğu görülmektedir.

\subsection{Regresyon Analizi Sonuçları}

Benlik-marka bağının marka aşkı, marka deneyimi ve marka sadakati üzerindeki etkisinin belirlenmesi amacıyla doğrusal regresyon analizi yapıımıştır. Sonuçlar Tablo 2, Tablo 3 ve Tablo 4 'te gösterilmiştir.

Tablo 2: Marka Aşkı Üzerinde Benlik-Marka Bağının Etkisi

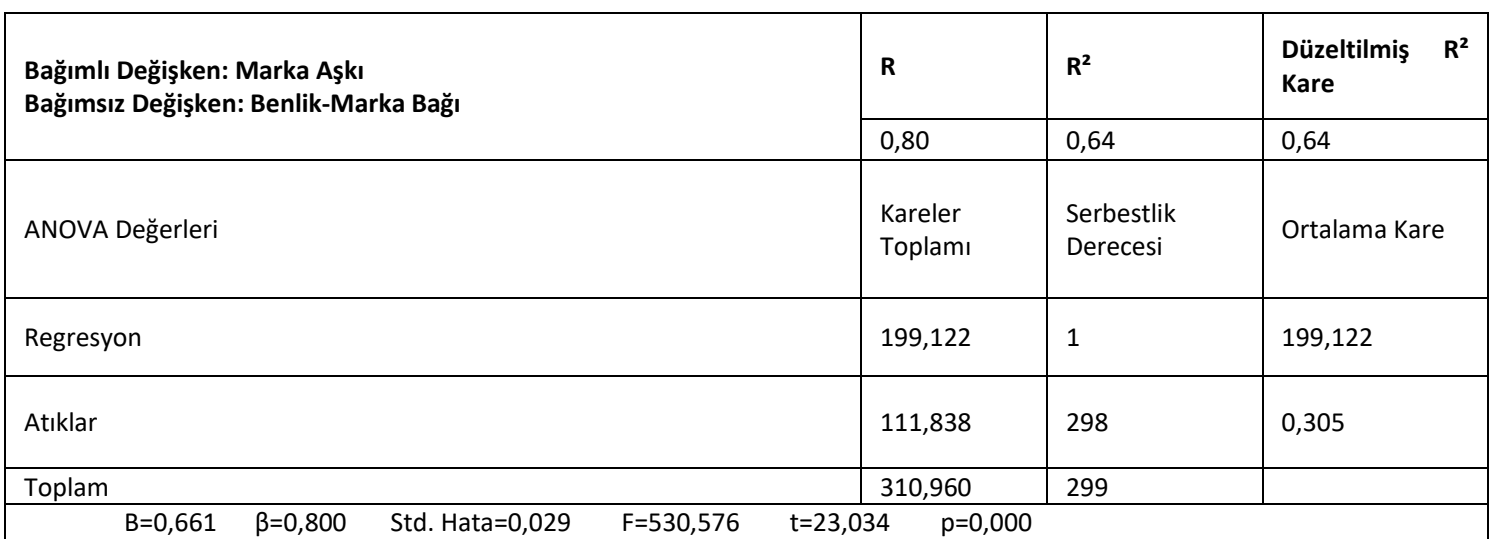

Tablo 2'de görüldüğü gibi oluşturulan regresyon modeli \%5 önem düzeyinde istatistikî açıdan anlamlıdır ve $\mathrm{R}^{2}$ değeri 0,64 olarak bulunmuştur. Modelde yer alan benlik-marka bağı marka aşkını etkilemektedir $(\beta=0,800: p=0,000<0,05)$. Bu sonuç ışığında $\mathrm{H}_{1}$ hipotezi kabul edilmiştir. Bireyin benliğiyle uyumlu gördüğü marklara yönelik duygusal yakınlık hissettiğini söylemek mümkündür. 
Tablo 3: Marka Deneyimi Üzerinde Benlik-Marka Bağının Etkisi

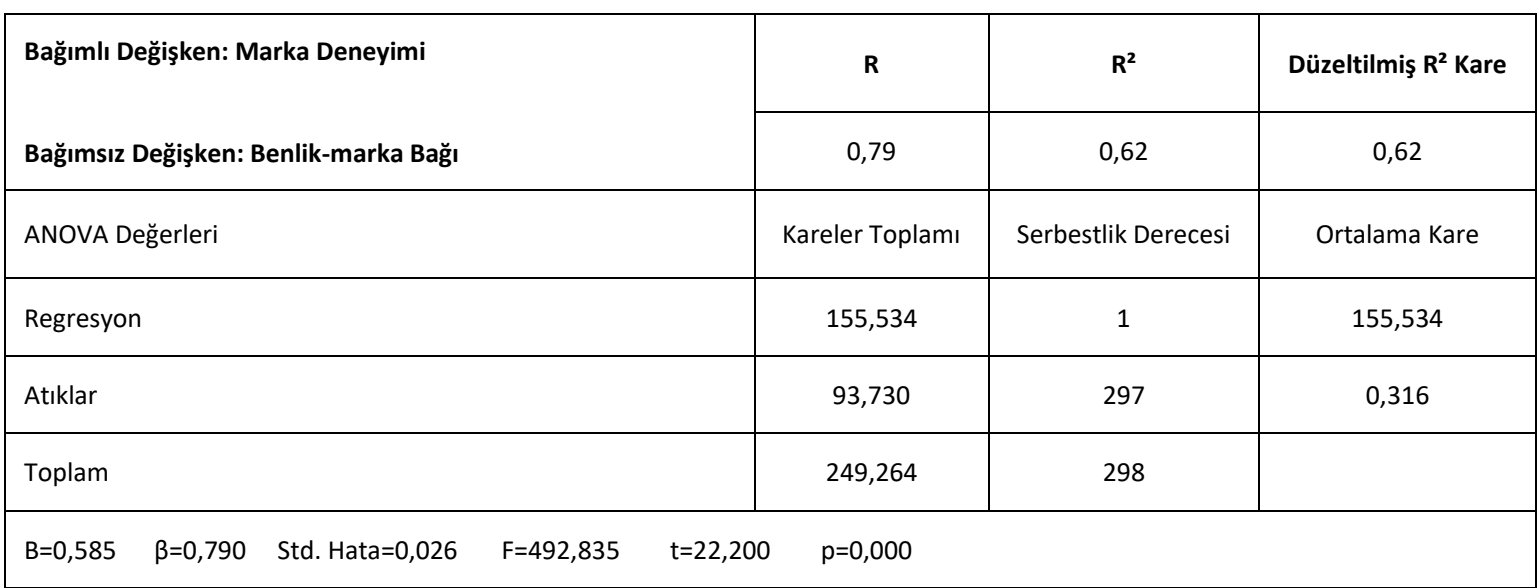

Tablo 3'de görüldüğü gibi oluşturulan regresyon modeli \%5 önem düzeyinde istatistiki açıdan anlamlıdır ve $\mathrm{R}^{2}$ değeri 0,62 olarak bulunmuştur. Modelde yer alan benlik-marka bağı marka deneyimini etkilemektedir ( $\beta=0,790$ : $p=0,000<0,05)$. Bu sonuç ışığında $\mathrm{H}_{2}$ hipotezi kabul edilmiştir. Bu doğrultuda insanlar öz kimliğiyle uyumlu gördüğü markalardan daha çok tecrübe kazanabilirler. Çünkü kişinin benliğiyle ilişki kurduğu markanın yaşatacağı deneyimlere vereceği yanıt daha olumlu olacaktır.

Tablo 4: Marka Sadakati Üzerinde Marka Aşkı, Marka Deneyiminin ve Benlik-marka Bağı Etkisi

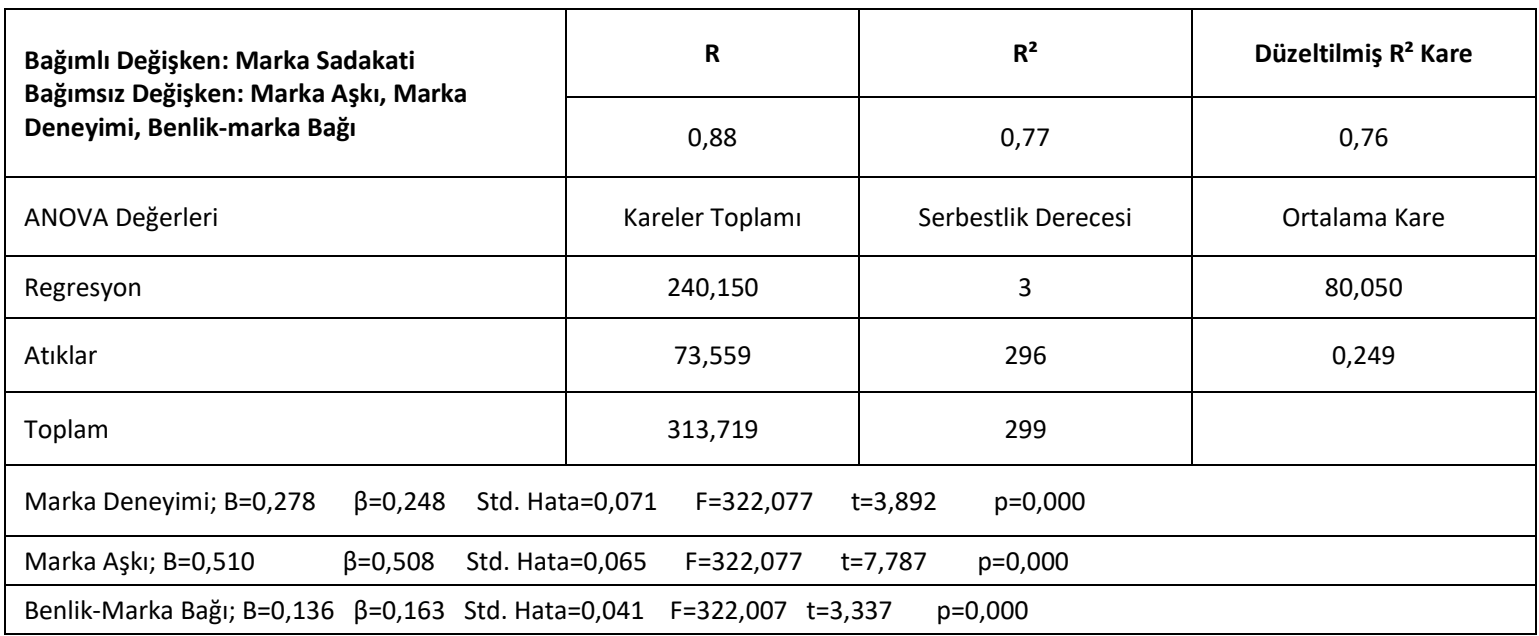

Tablo 4'de görüldüğü gibi oluşturulan çoklu regresyon modeli \%5 önem düzeyinde istatistikî açıdan anlamlıdır ve $\mathrm{R}^{2}$ değeri 0,77 olarak bulunmuştur. Modelde yer alan marka deneyimi, marka aşkı ve benlik-marka bağı marka sadakatini etkilemektedir $(\beta=0,248, \beta=0,508, \beta$ $=0,163 ; p=0,000<0.05$ ). Bu sonuçlar ışığında $\mathrm{H}_{6}, \mathrm{H}_{7}$ ve $\mathrm{H}_{3}$ hipotezleri kabul edilmiştir. Bu bağlamda markanın tekrar tekrar satın alınması veya müşterinin markaya kendini adaması için duygusal bir yakınlık kurulması, kişinin öz varlığıyla ahenk içerisinde olması ve markayla yaşadığı anıları hatırlaması önemlidir.

\subsection{Aracilık Etkisi Analizleri}

Aracı değişken; iki değişken arasındaki sebep-sonuç ilişkisinin bir parçasıdır (Mckinnon ve diğ., 2010: 594). Ayrıca araştırmalarda aracılık etkisi araştırıırken Baron ve Kenny (1986) tarafından önerilen aracı değişken analizi yöntemi kullanııımışır. Analize göre bağımsız değişkenin aracı değişkenin üzerinde etkisi olmalıdır. Ayrıca bağımlı değişken üzerinde bağımsız değişkenin etkisi olmalıdır. Son olarak ise aracı değişken analize dâhil edildiğinde bağımsız değişken ve bağımlı değişken arasındaki ilişkide azalma meydana gelmeli veya aradaki ilişki anlamsızlaşmalıdır (Baron ve Kenny, 1986: 1173).

Araşıırma modelinde aracı değişken olarak yer alan marka aşkı değişkeninin benlik-marka bağı ile marka sadakati değişkenleri arasında aracılık etkisinin olup olmadığı regresyon analizi ile incelenmiştir. Tablo 5'de benlik-marka bağı ile marka sadakati arasında marka aşkının aracılık etkisi analizinin sonuçları gösterilmiştir. 
Tablo 5: Benlik-marka Bağı ile Marka Sadakati Arasında Marka Aşkııın Aracılık Etkisi

\begin{tabular}{|c|c|c|c|c|c|c|c|c|}
\hline Adımlar & B & Std. Hata & $\beta$ & $t$ & $R^{2}$ & Düz. $R^{2}$ & $\mathbf{F}$ & p \\
\hline $\begin{array}{l}\text { 1.Adım: } \\
\text { Benlik-marka Bağı } \\
\text { Marka Aşkı }\end{array}$ & 0,661 & 0,029 & 0,800 & 23,034 & 0,640 & 0,639 & 530,576 & 0,000 \\
\hline $\begin{array}{l}\text { 2.Adım: } \\
\text { Benlik-marka Bağı } \\
\text { Marka Sadakati }\end{array}$ & 0,635 & 0,031 & 0,765 & 20,506 & 0,585 & 0,584 & 420,504 & 0,000 \\
\hline $\begin{array}{l}\text { 3.Adım: } \\
\text { Benlik-marka Bağı }\end{array}$ & 0,177 & 0,040 & 0,214 & 4,455 & 0,755 & 0,754 & 456,909 & 0,000 \\
\hline $\begin{array}{l}\text { Marka Aşkı Marka } \\
\text { Sadakati }\end{array}$ & 0,693 & 0,048 & 0,688 & 14,340 & & & & \\
\hline \multicolumn{9}{|c|}{$\begin{array}{lll}\text { Tolerans }=0,359 & \mathrm{VIF}=2,788 & \mathrm{p}=0,000\end{array}$} \\
\hline
\end{tabular}

Tablo 5'de görüldüğü üzere, birinci adımda benlik-marka bağının marka aşkı üzerinde istatistiksel olarak anlamlı bir etkisi vardır $(\beta=0,800$; $p=0,000)$. íkinci adımda, benlik-marka bağı ile marka sadakati arasında istatistiksel olarak anlamlı bir etki tespit edilmiştir $(\beta=0,765 ; p=0,000)$. Son olarak üçüncü adımda, benlik-marka bağı ve marka sadakati ile marka aşkı (aracı değişken) modele dâhil edilmiş ve sonucun istatistiksel olarak anlamlı olduğu saptanmıştır $(\beta=0,214 ; p=0,000)$. íkinci adımla karşılaştııılığında üçüncü adımın Beta $(\beta)$ değerinde azalma olduğu görülmektedir. Beta değerindeki azalmanın anlamlı olup olmadığının tespit edilmesi için Sobel Testi yapılmıştır. Sobel Testi neticesinde üçüncü adımın Beta değerindeki düşüşün istatistiksel olarak anlamlı olduğu görülmüştür $(Z=12,719 ; p=0,000)$. Son olarak üçüncü adımda analize dâhil edilen bağımsız değişkenler arasında çoklu doğrusallık (multicollinearity) olmadığı belirlenmiştir (Tolerans $=0,359>0,2$; $\mathrm{VIF}=2,788<5)$. Bu sonuçlar doğrultusunda, benlik-marka bă̆ı ile marka sadakati arasında marka aşkının aracılık etkisinin olduğu belirlenmiş ve $\mathrm{H}_{4}$ hipotezi kabul edilmiştir. Bireyin kimliğiyle uyumla olan markaya duyduğu bağlılığa duygularının da etki ettiği görülmektedir.

Araştırma modelinde aracı değişken olarak yer alan marka deneyimi değişkeninin benlik-marka bağı ile marka sadakati değişkenleri arasında aracııık etkisinin olup olmadığı regresyon analizi ile incelenmiştir. Tablo 6' da benlik-marka bağı ile marka sadakati arasında marka deneyiminin aracılık etkisi analizinin sonuçları gösterilmiştir.

Tablo 6: Benlik-marka Bağı ile Marka Sadakati Arasında Marka Deneyiminin Aracılık Etkisi

\begin{tabular}{|l|c|c|c|c|c|c|c|c|}
\hline Adımlar & B & Std. Hata & $\boldsymbol{\beta}$ & $\mathbf{t}$ & $\mathbf{R}^{\mathbf{2}}$ & Düz. $\mathbf{R}^{\mathbf{2}}$ & $\mathbf{F}$ & $\mathbf{p}$ \\
\hline $\begin{array}{l}\text { 1.Adım: } \\
\text { Benlik-marka Bağı } \\
\text { Marka Deneyimi }\end{array}$ & 0,585 & 0,026 & 0,790 & 22,200 & 0,624 & 0,623 & 492,835 & 0,000 \\
\hline $\begin{array}{l}\text { 2.Adım: } \\
\text { Benlik-marka Bağı } \\
\text { Marka Sadakati }\end{array}$ & 0,635 & 0,031 & 0,765 & 20,506 & 0,585 & 0,584 & 420,504 & 0,000 \\
\hline $\begin{array}{l}\text { 3.Adım: } \\
\begin{array}{l}\text { Benlik-marka Bağı } \\
\text { Marka Deneyimi } \\
\text { Marka Sadakati }\end{array}\end{array}$ & 0,239 & 0,042 & 0,288 & 5,746 & 0,721 & 0,719 & 380,415 & 0,000 \\
\cline { 2 - 10 } & 0,056 & 0,602 & 12,001 & & & & \\
\hline
\end{tabular}

Tablo 6'da görüldüğü üzere, birinci adımda benlik-marka bağının marka deneyimi üzerinde istatistiksel olarak anlamlı bir etkisi vardır $(\beta=0,790 ; p=0,000)$. íkinci adımda, benlik-marka bağı ile marka sadakati arasında istatistiksel olarak anlamlı bir etki tespit edilmiştir $(\beta=0,765$; $\mathrm{p}=0,000$ ). Son olarak üçüncü adımda, benlik-marka bağı ve marka sadakati ile marka deneyimi (aracı değişken) modele dâhil edilmiş ve sonucun istatistiksel olarak anlamlı olduğu saptanmıştı $(\beta=0,288 ; p=0,000)$. ikinci adımla karşılaştıııldığında üçüncü adımın Beta ( $\beta$ ) değerinde azalma olduğu görülmektedir. Beta değerindeki azalmanın anlamlı olup olmadığının tespit edilmesi için Sobel Testi yapılmıştır. Sobel Testi neticesinde üçüncü adımın Beta değerindeki düşüşün istatistiksel olarak anlamlı olduğu görülmüştür $(Z=10,134 ; p=0,000)$. Son olarak üçüncü adımda analize dâhil edilen bağımsız değişkenler arasında çoklu doğrusallık (multicollinearity) olmadığı belirlenmiştir (Tolerans $=0,376>0,2$; $\mathrm{VIF}=2,660<5)$. Bu sonuçlar doğrultusunda, benlik-marka bağı ile marka sadakati arasında marka deneyiminin aracılık etkisinin olduğu belirlenmiş ve $\mathrm{H}_{5}$ hipotezi kabul edilmiştir. Bireyin kimliğiyle uyumla olan markaya duyduğu bağ|ıı̆a yaşadığı tecrübeler veya kazandığı deneyimler etki etmektedir.

\section{SONUÇ VE ÖNERILER}

Rekabetin yoğun olduğu pazarlarda marka bağlılı̆̆ı yaratabilmek firmaya uzun vadede karlılık ve stratejik avantaj sağlamaktadır. Özellikle teknolojinin hızı gelişmesiyle ürünler arasındaki farklııkların ortadan kalkması, firmaların marka sadakati oluşturacak unsurları doğru tespit etmesini gerekli kılmaktadır. Çalışma kapsamında cep telefonu sektöründeki firmaların diğer işletmelerden kendini ayırt etmesini sağlayacak 
bir diğer ifadeyle marka sadakati oluşturabilecek öğeler araştırılmıştır. Marka sadakatini etkileyen unsurlar olarak; benlik-marka bağı, marka aşkı ve marka deneyimi ele alınmıştır. Elde edilen bulgulardan şu sonuçlara ulaşılmıştır:

Benlik-marka bağının marka aşkı ve marka deneyimi üzerinde anlamlı etkisi bulunmaktadır (Van der Westhuizen, 2018; Hwang ve Kandampully, 2012). Benlik-marka bağının marka aşkı üzerindeki etkisi ele alındığında bireyi tam olarak anlayan veya tanıyan firmalar müşteri ile marka arasında güçlü duygular yaratabilirler. Çünkü birey benliğiyle, duygularıyla ve markaya duyduğu aşkla bir bütündür. Dolayısıyla marka bireyi ne kadar yansıtırsa müşteri o kadar marka için tutkulu duygular hissedecektir. Benlik-marka bağının marka deneyimi üzerindeki etkisi incelendiğinde ise kendisiyle uyumlu olan markları tercih eden müşterilerin o markayı bütünüyle daha çok sahiplendiği gözlenmektedir. Markanın bireyin benliğine uygun olması müşterilerin yaşayacağı deneyimi etkilemektedir. Bu bulgular doğrultusunda firmalara şu önerilerde bulunulabilir; müşteriler yakından tanınmalı, özel ilgi alanları ve istekleri belirlenmeye çalışılmalı, bu konuda teknolojinin sunduğu fırsatlardan yararlanılmalıdır. Sosyal medya hesapları firmalar tarafından aktif kullanılmalıdır. Ayrıca bu mecrayı fırsata çevirmek için tüketicilerin ilgi alanları dikkatlice incelenmelidir. Mobil iletişim araçları ise firmaların tüketicilerin düşüncelerini öğrenmek için kullanılabilecekleri diğer bir alandır.

Marka sadakati üzerinde marka aşkının, benlik-marka bağı ve marka deneyiminin etkisi olduğu görülmüştür (Van der Westhuizen, 2018; Hemsley-Brown ve Alnawas, 2016; Lin ve diğ., 2017; Huang, 2017; Hwang ve Kandampully, 2012). Marka aşkının marka sadakati üzerinde etkili olması ele alındığında tüketicilerin duygusal tercihleri marka bağıııklarını etkilemektedir. Bu sayede marka ve birey arasında yoğun duygular yaratabilen firmalar markaya yönelik sadakat oluşturabilirler. Duygusal yarar sağlayarak marka bağı oluşturan firmalar tüketicinin yaşadığı hazdan uzun vadeli karlılık olarak geri dönüş alabilirler. Marka sadakati üzerinde etkili olan diğer bir değişkenimiz ise benlik-marka bağıdır. Bireyin marka sadakati göstermesi için markada kendinden bir şeyler bulması, markanın bireyi yansıtması gerekir. Benliklerinden izler taşıyan markaları tercih eden müşteriler bu markalarla uzun vadeli ilişkiler kurmaya gönüllü olacaklardır. Marka deneyimi ise marka sadakati üzerinde etkili olan diğer bir değişkenimizdir. Markayla olumlu deneyim yaşayan müşterilerin yaşadığı pozitif duygular onları memnun edecek ve hatta sadık bir müşteri olmalarında önemli katkı sağlayacaktır. Benliğin, aşsın, deneyimin sadakat üzerindeki etkisinden yola çıkarak firmalara şu önerilerde bulunulabilir; görülmektedir ki müşteriler duygusal yaklaşımlara önem vermektedirler. Firmalar somut özelliklerden ziyade duygulara yönelmelidirler. Reklamlarda ürünün rengi, logosu ve tasarımına daha estetik özellikler katmalıdırlar. Benlik kavramıyla anlatılmak istenen ise müşterinin öz kimliğidir. Bu yüzden bireyin markayı tercih etme sebebi belirlenip ona göre tanıtımlar yapılmalıdır. Örneğin gösterişçi tüketim veya statü kazanmak için tercih edilen bir marka için fiyat olgusundan ziyade kullanımdan doğacak statü kazanımı vurgulanmalıdır. Ayrıca markanın kendine has özellikleri olmalı, bu bazen renk bazen bir logo veya tasarım olabilir. Kimi zaman ise bireyin markayla benlik bağı kurmasının ardında markanın hikayesi karşımıza çıkabilir. Benzer şekilde bireyin duygularına ve deneyimlere hitap etmede çalışanlar da önemli rol oynamaktadır. Çalışanların markanın savunucu olması ve müşterinin olumlu anılar yaşamasına katkıda bulunması gerekir. Marka deneyimi boyutlarından düşünsel yaklaşım ise sadakatin oluşması için akla veya zihne hitap etmenin göz ardı edilmemesi gerektiğini gösterir. Böyle bir durumda ise tüketicinin ihtiyacının marka tarafından karşılanıp karşılanmadığı sorgulanır. Firmanın yapması gereken ise ihtiyaçları tam olarak belirlemekle yetinmeyip karşılanmamış ihtiyaçları ve müşterinin şikâyetlerini çözüme ulaştırmaktır. Bu yüzden firmalar marklarına tutkun müşteriler yaratmak isterken markanın çağrışımlarına dikkat etmelidirler. Günümüzde özellikle çevreye duyarlı markalar müşteri nezdinde daha olumlu algılanmaktadır. Cep telefonu sektörü açısından düşünüldüğünde geri dönüşüme katkı sağlanabilir. Firmalar üretim süreçlerinde doğayı düşünerek faaliyet gösterebilir. Zihinlerde yer edinebilmek için maskotlar kullanabilir. Bu sayede marka hem duyguları harekete geçirir hem de daha cezbedici bir hal alır.

Çalışmanın asıl amacını oluşturan aracılık etkisine ilişkin bulgular ise marka aşkı ve marka deneyiminin benlik-marka bağı ve marka sadakati arasında aracılık etkisine sahip olmasıdır (Van der Westhuizen, 2018; Aydın, 2017). Müşterinin benliğiyle marka arasında ilişki kurması veya markanın tüketicinin benliğini yansıtımıyla yaşanan marka aşkı marka sadakati üzerindeki etkiyi arttıracaktır. Benliğiyle marka arasında bağlantı olan bireylerin, marka aşkı yaşamakta ve gelişen marka aşkı sonucunda marka sadakati duymaktadırlar. Ayrıca marka deneyiminin aracılık etkisi ele alındığında ise; müşterinin benliğiyle marka arasında ilişki kurması veya markanın tüketiciyi yansıtımıyla yaşanan marka deneyimi marka sadakati üzerindeki etkiyi arttıracaktır. Benliğiyle marka arasında bağlantı olan bireyler, marka deneyimi yaşamakta ve gelişen marka deneyimi sonucunda marka sadakati duymaktadırlar. Bu sonuçlar ışığında firmalar marka sadakati oluşturmada tüketiciyi yansıtan, onu doğru şekilde tanımlayan özelliklerin üzerinde durmanın yanı sıra aşk ve deneyim unsurlarını da dikkate alarak bağlılık düzeyini etkileyebilirler. Bu sonuçlar göstermedik ki insanların psikolojik yapısı bir bütün içerisindedir. Bireyin içsel yapısını içeren benliği ile yaşadığı duygularının örtüşmesi bağlılıklarını etkilemektedir.

\section{KAYNAKÇA}

Aaker, D. A. (2009). Marka Değeri Yönetimi: Bir Marka İsminin Değerinden Yararlanmak. İstanbul: MediaCat Kitapları.

Ahuvia, A. C. (1993). I Love It! Towards a Unifying Theory of Love Across Diverse Love Objects. (Yayınlanmamış Doktora Tezi), USA: Michigan University.

Aguirre-Rodriguez, A., Bosnjak, M., Sirgy, M. J. (2012). Moderators of the Self-Congruity Effect on Consumer Decision-Making: A MetaAnalysis. Journal of Business Research, 65(8), 1179-1188.

Algharabat, R. S. (2017). Linking Social Media Marketing Activities With Brand Love: The Mediating Role of Self-Expressive Brands. Kybernetes, 46(10), 1801-1819.

Alnawas, I., Altarifi, S. (2016). Exploring The Role of Brand Identification and Brand Love in Generating Higher Levels of Brand Loyalty. Journal of Vacation Marketing, 22(2), 111-128. 
Aydın, H. (2017). Marka Güveni, Farkındalığı ve Benlik İmaj Uyumunun Marka Bağlılığına Etkisinde Marka Aşkının Aracılık Rolü, Ege Academic Review, 17(2), 281-294.

Baron, R. M., Kenny, D. A. (1986). The Moderator-Mediator Variable Distinctionin Social Psychological Research: Conceptual, Strategic, and Statistical Considerations. Journal of Personality and Social Psychology, 51 (6), 1173-1182.

Batı, U. (2013). Markethink ya da Farkethink "Deneyimsel Pazarlama ve Duyusal Markalama". İstanbul: Destek Yayınları.

Beckman, E., Kumar, A., Kim, Y. K. (2014). The Impact of Brand Experience on Downtown Success. Journal of Travel Research, 52, 646-658.

Brakus, J. J., Schmitt, B. H., Zarantonello, L. (2009). Brand Experience: What is It? How is It Measured? Does It Affect Loyalty?. Journal of Marketing, 73, 52- 68.

Brink, D. V., Gaby, O. S., Pieter, P. (2006). The Effect of Strategic and Tactical Cause-Related Marketing on Consumers' Brand Loyalty. Journal of Consumer Marketing, 23(1), 15-25.

Carroll, B. A., Ahuvia, A. C. (2006). Some Antecedents and Outcomes of Brand Love. Marketing Letters, 17(2), 79-89.

Chang, P. L., Chieng, M. H. (2006). Building Consumer-Brand Relationship: A Cross Cultural Experiential View. Psychology and Marketing, 23(11), 927-959.

Chaudhuri, A., Holbrook, M. (2001). The Chain Of Effects From Brand Trust and Brand Affect to Brand Performance. Journal of Marketing, 65(2), 81-93.

Dirsehan, T. (2010). Örneklerle Temel Deneyimsel Pazarlama, İstanbul: İkinci Adam Yayınları.

Eelen, J., Özturan, P., Verlegh, P. W. (2017). The Differential Impact of Brand Loyalty on Traditional and Online Word of Mouth: The Moderating Roles of Self-Brand Connection and The Desire to Help The Brand. International Journal of Research in Marketing, 34(4), 872891.

Erciş, A., Yıldız, T., Türk, B. (2017). The Influence of Customer Value, Brand Trust, and Self Congruity in Creating Emotional Brand Attachment. [Bildiri], 7th International Conference on Leadership, Technology, Innovation and Business Management (ICLTIBM-2017). Marmaris.

Escalas, J. E., Betmann, J. R. (2003). You Are What They Eat: The Influence of Reference Groups on Consumers' Connections to Brands. Journal of Consumer Psychology, 13(3), 339-348.

Escalas, J. E. (2004). Narrative Processing: Building Consumer Connections to Brands.Journal of Consumer Psychology, 14(1/2), 168-180.

Escalas, J. E., Bettman, J. R. (2005).Self-Construal, Reference Groups, and Brand Meaning.Journal of Consumer Research, 32(3), 378-389.

Fandos, C., Flavian, C. (2006). Intrinsic and Extrinsic Quality Attributes, Loyalty and Buying Intention: An Analysis for a PDO Product. British Food Journal, 108(8), 646-662.

Ferraro, R., Kirmani, A., Matherly, T. (2013). Look at Me! Look at Me! Conspicuous Brand Usage, Self-Brand Connection and Dilution. Journal of Marketing Research, 50(4), 477-488.

Fitzgibbon, C., White, L. (2004). The Role of Attitudinal Loyalty in The Development of Customer Relationship Management Strategy within Service Firms. Journal of Financial Services Marketing, 9(3), 214-230.

Fournier, S. (1998). Consumers and Their Brands: Developing Relationship Theory in Consumer Research. Journal of Consumer Research, 24(4), 343-373.

Garg, R., Mukherjee, J., Biswas, S., Kataria, A. (2016). An Investigation into the Concept of Brand Love and Its Proximal and Distal Covariates. Journal of Relationship Marketing, 15(3), 135- 153.

Grubb, E. L., Grathwohl, H. L. (1967). Consumer Self-Concept, Symbolism and Market Behavior: A Theoretical Approach. Journal of Marketing, $31(4), 22-27$

Ha, C. L. (1998). The Theory of Reasoned Action Applied to Brand Loyalty. Journal of Product \& Brand Management, 7, 51-61.

Hemsley-Brown, J., Alnawas, I. (2016). Service Quality and Brand Loyalty: The Mediation Effect of Brand Passion, Brand Affection and SelfBrand Connection. International Journal of Contemporary Hospitality Management, 28(12), 2771-2794.

Huang, C. C. (2017). The Impacts of Brand Experiences on Brand Loyalty: Mediators of Brand Love and Trust. Management Decision, 55(5), 915-934.

Hussein, A. S. (2018). Effects of Brand Experience on Brand Loyalty in Indonesian Casual Dining Restaurant: Roles of Customer Satisfaction and Brand of Origin. Tourism and Hospitality Management, 24(1), 119-132.

Hwang, J., Kandampully, J. (2012). The Role of Emotional Aspects in Younger Consumer-Brand Relationships.Journal of Product \& Brand Management, 21(2), 98-108.

Khan, I., Rahman, Z. (2015). Brand Experience Anatomy in Retailing: An Interpretive Structural Modeling Approach. Journal of Retailing and Consumer Services, 24, 60-69. 
Knapp, D. E. (1999). Brand Mindset: Five Essential Strategies for Building Brand Advantage Throughout Your Company. New York: McGrawHill Companies.

Konuk, G. (2014). Deneyimsel Pazarlama, Ankara: Detay Yayıncılık.

Kotler, P., Keller, K. L. (2009). Marketing Management. 13. Edition. New Jersey: Pearson Education Inc.

Kumari, N., Patyal, S. (2017). Customer to Customer: Attitudinal and Behavioural Loyalty. International Journal of Management Studies, 4(1), 115-121.

Lee, S. A., Jeong, M. (2014). Enhancing Online Brand Experiences: An Application of Congruity Theory. International Journal of Hospitality Management, 40, 49-58.

Lin, J., Lobo, A., Leckie, C. (2017). The Role of Benefits and Transparency in Shaping Consumers' Green Perceived Value, Self-Brand Connection and Brand Loyalty. Journal of Retailing and Consumer Services, 35, 133-141.

Liu, F., Li, J., Mizerski, D., Soh, H. (2012). Self-Congruity, Brand Attitude, and Brand Loyalty: A Study on Luxury Brands. European Journal of Marketing, 46(7/8), 922-937.

Mascarenhas, O. A., Ram, K., Michael, B. (2006). Lasting Customer Loyalty: A Total Customer Experience Approach. Journal of Consumer Marketing, 23(7), 397-405.

McKinnon, D. P., Fairchild, A. J., Fritz, M. S. (2010). Mediation Analysis. Annual Review of Psychology, 58, $593-614$.

Nadiri, H., Günay, G. N. (2013). An Empirical Study to Diagnose the Outcomes of Customers' Experiences in Trendy Coffee Shops. Journal of Business Economics and Management, 14(1), 22-53.

Oliver, R. L. (1999). Whence Consumer Loyalty?. Journal of Marketing, 63, 33-44.

Onan, G. (2006). Hizmet Sektöründe Marka Sadakati ve TEB Üzerine Bir Uygulama. (Yayımlanmamış Yüksek Lisans Tezi). İzmir: Dokuz Eylül Üniversitesi.

Ridgway, J. L. (2011). Brand Personality: Consumer's Perceptions of Color Used in Brand Logos. (Yayınlanmamış Doktora Tezi), COLUMBIA: University of Missouri

Schmitt, B. H. (1999). Experiential Marketing. Journal of Marketing Management, 15(1-3), 53-67.

Schmitt, B. H. (2003). Customer Experience Management: A Revolutionary Approach to Connecting with Your Costomer. New Jersey: John Wiley \& Sons.

Schmitt, B. H., Rogers, D. L. (2008). Handbook on Brand and Experience Management. USA: Edward Elgar Publishing Limited.

Schmitt, B. (2010). Experience Marketing: Concepts, Frameworks and Consumer Insights. Foundations and Trends in Marketing, 5(2), 55-112.

Schoenbachler, D. D., Geoffrey L. G., Timothy W. A. (2004). Building Brand Loyalty Through Individual Stock Ownership. Journal of Product \& Brand Management, 13, 488-497.

Shimp, T. A., Madden, T. J. (1988). Consumer-Object Relations: A Conceptual Framework Based Analogously on Sternberg's Triangular Theory of Love. Advances in Consumer Research, 15(1), 163-168.

Sirgy, M. J., Johar, J. S., Samli, A. C., Claiborne, C. B. (1991). Self-Congruity Versus Functional Congruity: Predictors of Consumer Behavior. Journal of the Academy of Marketing Science, 19(4), 363-375.

Stenberg, R. J. (1986). A Triangular Theory of Love. Psychological Review, 93(2), 119-135.

Uşaklı, A., Baloğlu, S. (2011). Brand Personality of Tourist Destinations: An Application of Self-Congruity Theory. Tourism Management, 32(1), 114-127.

Van der Westhuizen, L. M. (2018). Brand Loyalty: Exploring Self-Brand Connection and Brand Experience. Journal of Product \& Brand Management, 27(2), 172-184.

Yang, J., Zheng, R., Zhao, L., Gupta, S. (2017). Enhancing Customer Brand Experience and Loyalty Through Enterprise Microblogs: Empirical Evidence from a Communication Framework Perspective. Information Technology \& People, 30(3), 580-601.

Zarantonello, L., Schmitt, B. H. (2010). Using the Brand Experience Scale to Profile Consumers and Predict Customer Behavior. Journal of Brand Management, 17(7), 532-540. 